\title{
PENERAPAN METODE PENEMUAN TERBIMBING DALAM UPAYA MENINGKATKAN KEMAMPUAN PEMAHAMAN KONSEP MATEMATIKA DI KELAS VIII SMP NEGERI 1 AJIBATA
}

\author{
${ }^{1}$ Mariani Manik, ${ }^{2}$ Mukhtar \\ ${ }^{1}$ Fakultas Matematika dan Ilmu Pengetahuan Alam, Universitas Negeri Medan \\ ${ }^{2}$ Dosen Fakultas Matematika dan Ilmu Pengetahuan Alam, Universitas Negeri Medan \\ Email: marianirekayasa@gmail.com
}

\begin{abstract}
ABSTRAK
Penelitian ini bertujuan untuk mengetahui peningkatan kemampuan pemahaman konsep matematika siswa di kelas VIII SMP Negeri 1 Ajibata setelah diterapkan metode Penemuan Terbimbing dan mengetahui aktivitas belajar siswa ketika diterapkan metode Penemuan Terbimbing. Penelitian ini adalah penelitian tindakan kelas yang dilaksanakan dalam 2 siklus yang masing-masing siklus dilaksanakan dalam 2 kali pertemuan. Subjek dalam penelitian ini adalah siswa kelas VIII-A yang berjumlah 30 orang. Objek dalam penelitian ini adalah upaya meningkatkan kemampuan pemahaman konsep matematika siswa pada materi Prisma dan Limas. Data diperoleh dari tes pemahaman konsep matematika siswa pada akhir setiap siklus dan lembar observasi untuk setiap kali pertemuan. Hasil penelitian menunjukkan bahwa kemampuan Pemahaman konsep matematika siswa mengalami peningkatan. Ini dapat dilihat dari nilai rata-rata pemahaman konsep matematika siswa pada tes awal yaitu 58,83 dengan tingkat pemahaman rendah. Secara klasikal dari 30 siswa hanya 2 siswa $(6,67 \%)$ yang mencapai peningkatan kemampuan pemahaman konsep (mencapai nilai $\geq 75$ ). Setelah pelaksanaan tindakan pada siklus I, nilai rata-rata pemahaman konsep matematika siswa meningkat menjadi 70,91 dengan tingkat pemahaman sedang dan jumlah siswa yang mencapai peningkatan sebanyak 14 siswa (46,67\%). Selanjutnya setelah pelaksanaan tindakan pada siklus II, nilai rata-rata pemahaman konsep matematika siswa meningkat menjadi 81,91 dengan tingkat pemahaman tinggi dan sebanyak 26 siswa (86,67\%) mencapai peningkatan, serta telah mencapai indicator keberhasilan penelitian. Berdasarkan hasil penelitian dapat disimpulkan bahwa metode Penemuan Terbimbing dapat meningkatkan kemampuan pemahaman konsep matematika siswa pada materi Prisma dan Limas.
\end{abstract}

Kata Kunci : Kemampuan Pemahaman Konsep, Metode Penemuan Terbimbing, Prisma dan Limas.

\begin{abstract}
This study aims to determine the improvement of the ability to understand the concepts of mathematics students in class VIII SMP Negeri 1 Ajibata after applied Guided Discovery method and to know the student's learning activity when applied method of Guided Discovery. This study is a classroom action research conducted in 2 cycles, each cycle is held in 2 meetings. Subjects in this study were students of class VIII-A which amounted to 30 people. Objects in this research is an effort to improve the ability of students'
\end{abstract}

Mariani Manik, Mukhtar Penerapan Metode Penemuan Terbimbing dalam Upaya Meningkatkan Kemampuan Pemahaman Konsep Matematika di Kelas VIII SMP Negeri 1 Ajibata. Jurnal Inspiratif, Vol. 3, No. 2 Agustus 2017. 
understanding of mathematical concepts on Prism and Limas material in class VIII-A SMP Negeri 1 Ajibata academic year 2016/2017. The data were obtained from a comprehension test of students' mathematical concepts at the end of each cycle and an observation sheet for each meeting. The results showed that the ability to understand the concept of mathematics students have increased. This can be seen from the average score of understanding of mathematical concepts of students on the initial test that is 58.83 with low understanding level. Classically of 30 students only 2 students $(6.67 \%)$ who achieved improvement of concept comprehension ability (reaching value $\geq 75$ ). After the implementation of the action on the first cycle, the average score of students' mathematical concepts comprehension increased to 70.91 with a moderate level of understanding and the number of students who achieved an increase of 14 students (46.67\%). Furthermore, after the implementation of the action in cycle II, the average score of understanding of mathematical concepts of students increased to 81.91 with a high level of understanding and as many as 26 students (86.67\%) achieved improvement, and has achieved the indicator of research success. Based on the result of the research, it can be concluded that Guided Discovery method can improve students' mathematical concept comprehension on Prism and Limas material.

Keywords: Ability to Understand Concepts, Guided Discovery Methods, Prisms and Limas.

\section{Pendahuluan}

Pendidikan tidak dapat dilepaskan dari kehidupan manusia karena merupakan kebutuhan manusia sepanjang hidupnya. Pendidikan menjadi sarana untuk mengembangkan potensi, sehingga yang bersangkutan mampu menghadapi dan memecahkan problema kehidupan yang dialaminya. Dewasa ini manusia harus menghadapi perkembangan Ilmu Pengetahuan dan Teknologi (IPTEK) yang begitu cepat. Pendidikan menjadi salah satu faktor yang sangat penting dalam meningkatkan sumber daya manusia (SDM) yang berkualitas dan mampu berkompetensi dengan IPTEK.

Pada Bab II Pasal 3 UndangUndang Republik Indonesia No.20 tahun 2003 tentang Sistem Pendidikan Nasional dijelaskan bahwa:

Pendidikan nasional berfungsi mengembangkan kemampuan dan membentuk watak serta peradaban bangsa yang bermartabat dalam rangka mencerdaskan kehidupan suatu bangsa. Pendidikan bertujuan untuk mengembangkan potensi peserta didik agar menjadi manusia yang beriman dan bertaqwa kepada Tuhan Yang Maha Esa, berakhlak mulia, sehat, berilmu, cakap, kreatif, mandiri, dan menjadi warga negara yang demokratis serta bertanggung jawab.

Di dalam dunia pendidikan, matematika merupakan salah satu ilmu bantu yang sangat penting dan berguna dalam kehidupan sehari-hari. Selain itu, matematika juga tidak dapat dipisahkan dari ilmu pengetahuan dan teknologi. Untuk penguasaan teknologi dimasa depan diperlukan penguasaan matematika yang memadai. Hal ini dikarenakan matematika dapat melatih seseorang untuk berpikir secara logis, kritis, kreatif, dan terampil untuk menyelesaikan masalah dalam kehidupan sehari-hari. Matematika merupakan sarana penting yang berkontribusi menjadi sarana berfikir ilmiah yang sangat diperlukan untuk mengembangkan daya pikir dan kemampuan logis. Santoso (dalam Hujodo, 2001: 25) menyatakan bahwa "kemajuan negara-negara maju, hingga sekarang menjadi dominan ternyata $60 \%$

Mariani Manik, Mukhtar Penerapan Metode Penemuan Terbimbing dalam Upaya Meningkatkan Kemampuan Pemahaman Konsep Matematika di Kelas VIII SMP Negeri 1 Ajibata. Jurnal Inspiratif, Vol. 3, No. 2 Agustus 2017. 
- $80 \%$ menggantungkan kepada matematika".

Hal senada juga disampikan oleh Hariyati, Indaryanti dan Zulkardi (2008:51) yang mengemukakan bahwa "matematika merupakan ilmu universal yang mendasari perkembangan teknologi modern, mempunyai peran penting dalam berbagai disiplin dan memajukan daya pikir manusia. Oleh karena itu matematika dapat digunakan sebagai sarana untuk memecahkan masalah kehidupan sehari-hari". Artinya perkembangan pesat di bidang teknologi, informasi dan komunikasi dewasa ini dilandasi oleh perkembangan matematika dan untuk menguasai dan menciptakan teknologi di masa depan diperlukan penguasaan matematika yang kuat sejak dini.

Mata pelajaran matematika diajarkan pada setiap jenjang pendidikan mulai dari prasekolah (TK), SD, SMP, SMA, sampai pada tingkat perguruan tinggi. Matematika juga dipakai sebagai tolak ukur kelulusan siswa pada ujian nasional. Seperti yang tercantung dalam Kurikulum Tingkat Satuan Pendidikan (dalam Depdiknas, 2006) bahwa "mata pelajaran matematika perlu diberikan kepada semua peserta didik mulai dari sekolah dasar untuk membekali peserta didik kemampuan berpikir logis, analitis, sistematis, kritis, dan kreatif, serta kemampuan bekerjasama”. Cornelius (dalam Abdurrahman, 2012:204) juga mengungkapkan pentingnya siswa belajar matematika, yaitu karena matematika merupakan "(1) sarana berpikir yang jelas dan logis, (2) sarana untuk memecahkan masalah kehidupan sehari-hari, (3) sarana mengenal pola-pola hubungan dan generalisasi pengalaman, (4) sarana untuk mengembangkan kreativitas, dan (5) sarana untuk meningkatkan kesadaran terhadap perkembangan budaya".

Ironisnya, pentingnya pembelajaran matematika tidak sejalan dengan minat dan prestasi siswa dalam mempelajari matematika. Kenyataan di lapangan menunjukkan prestasi belajar siswa dibidang matematika masih rendah. Hal ini tercermin dari hasil penelitian TIMSS (Trends in International Mathematics and Science Study) yang diikuti siswa kelas VIII Indonesia tahun 2011 untuk bidang matematika, Indonesia berada diurutan ke-38 dari 42 negara yang siswanya di tes dengan skor 386, sedangkan skor rata-rata internasional 500 (Napitupulu, 2012).

Matematika saat ini menjadi mata pelajaran yang ditakuti karena dianggap sangat sulit. Sulitnya matematika disebabkan oleh kegiatan belajar mengajar di kelas khususnya pada saat pelajaran matematika masih mengalami beberapa kendala. Diantaranya adalah kegiatan belajar yang saat ini terlaksana di kelas masih bersifat teacher centered yang menjadikan guru sebagai pusat atau sumber pembelajaran, sedangkan siswa sebagai objek pembelajaran. Seperti yang dinyatakan oleh Shoimin (2014:17) "Diakui atau tidak pada zaman yang modern ini, sebagian besar guru mengajar menggunakan metodologi mengajar konvensional. Cara mengajar tersebut berpusat kepada guru (teacher centered)". Hal tersebut akan berdampak pada kurangnya aktifitas siswa dalam proses pembelajaran matematika. Pembelajaran teacher centered akan menjadikan proses belajar menjadi kurang bermakna bagi siswa, kekuatan memori materi yang telah diajarkan oleh gurupun tidak akan bertahan dalam waktu yang lama, serta siswa kurang dapat mengembangkan ilmunya. Guru juga jarang mengaitkan pengetahuan yang dimiliki siswa sebelumnya dengan materi baru yang sedang diajarkan. Surya dan Syahputra (2017) menemukan kegagalan dalam matematika sekolah sebagian besar terkait dengan tradisi pengajaran yang tidak sesuai dengan cara kebanyakan siswa belajar.

Mariani Manik, Mukhtar Penerapan Metode Penemuan Terbimbing dalam Upaya Meningkatkan Kemampuan Pemahaman Konsep Matematika di Kelas VIII SMP Negeri 1 Ajibata. Jurnal Inspiratif, Vol. 3, No. 2 Agustus 2017. 


\begin{abstract}
Masalah lain yang juga ditemukan dalam pembelajaran matematika adalah siswa yang sulit memahami konsep matematika. Konsep diartikan sebagai ide abstrak yang mengelompokkan objek berdasarkan ciri-ciri atau karakteristik yang sama.
\end{abstract} Pada akhirnya siswa yang sulit memahami konsep akan cenderung menghapalkan konsep yang diberikan guru tanpa memahami maksud dari isinya. Sebagaimana dinyatakan oleh Dahar (2006:97) bahwa "guru dan bahan-bahan pelajaran sangat jarang menolong para siswa dalam menentukan dan menggunakan konsep-konsep relevan dalam struktur kognitif mereka untuk mengasimilasikan pengetahuan baru, akibatnya pada para siswa hanya terjadi belajar hapalan". Padahal pemahaman akan konsep adalah salah satu kecakapan matematika yang sangat perlu untuk dicapai. Sebagaimana tercantum pada SI mata pelajaran matematika (dalam Wardhani, 2008:2) bahwa salah satu tujuan pembelajaran matematika "agar siswa mampu memiliki kemampuan memahami konsep matematika, menjelaskan keterkaitan antar konsep dan mengaplikasikan konsep atau algoritma, secara luwes, akurat, dan efisien, dan tepat dalam pemecahan masalah". Masalah-masalah diatas diperkuat dengan hasil observasi dan wawancara yang penulis lakukan pada 16 Januari 2017 di SMP Negeri 1 Ajibata. Berdasarkan wawancara yang dilakukan dengan guru mata pelajaran matematika kelas VIII di SMP Negeri 1 Ajibata Para (Novita Sirait, S.Pd) mengatakan bahwa banyak siswa yang sulit memahami pelajaran matematika terutama pada materi prisma dan limas. Penulis juga melakukan wawancara kepada beberapa siswa yang sudah mempelajari prisma dan limas dan mereka juga mengaku bahwa materi itu termasuk materi yang sulit. Hal itulah yang menjadi dasar penulis dalam memilih materi prisma dan limas.
Dari hasil observasi yang dilakukan juga diketahui bahwa metode pembelajaran yang digunakan guru masih berpusat kepada guru. Penggunaan metode pembelajaran yang berpusat pada guru menyebabkan siswa tidak memiliki kesempatan untuk mengembangkan sendiri konsep matematika yang sudah dimilikinya untuk menemukan konsep selanjutnya. Ketidakmampuan tersebut akan membuat hasil belajar matematika siswa menjadi rendah.

Pada saat observasi penulis juga memberikan tes diagnostik sebanyak 4 soal kepada 30 orang siswa di kelas VIII-A dan diperoleh hasil yang tidak memuaskan. Tes yang diberikan berhubungan dengan materi dasar prisma dan limas yang sebelumnya telah diajarkan di bangku sekolah dasar, materi yang berhubungan dengan phytagoras dan bangun datar segiempat yaitu persegi dan persegi panjang. Alasan pemilihan materi tersebut karena merupakan materi prasyarat dari materi bangun ruang sisi datar dengan sub pokok bahasan prisma dan limas.

Dari 30 siswa yang mengikuti tes hanya 2 siswa yang nilai kemampuan pemahaman konsepnya mencapai nilai ketuntasan minimal (KKM), dimana nilai KKM adalah 75. Artinya yang tuntas kemampuan pemahaman konsepnya hanya sebesar $6,66 \%$ dan yang tidak tuntas ada 30 siswa atau sebesar 93,33\%. Rendahnya hasil tes diagnostik tersebut disebabkan oleh kurangnya kemampuan pemahaman konsep matematika siswa. Hal ini dapat kita lihat dari jawaban siswa pada soal yang diberikan :

Pada soal nomor 1 siswa diminta untuk menuliskan sifat-sifat persegi dan persegi panjang serta menggambarkannya.

Mariani Manik, Mukhtar Penerapan Metode Penemuan Terbimbing dalam Upaya Meningkatkan Kemampuan Pemahaman Konsep Matematika di Kelas VIII SMP Negeri 1 Ajibata. Jurnal Inspiratif, Vol. 3, No. 2 Agustus 2017. 


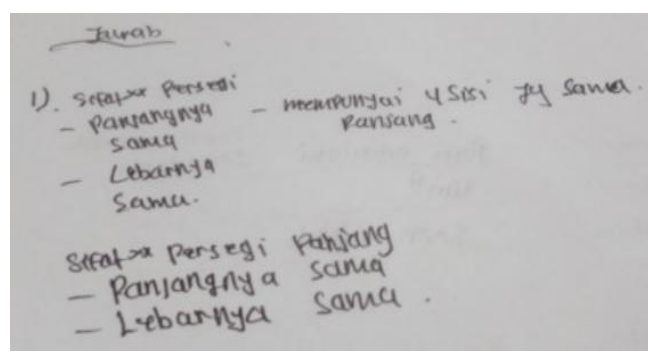

Gambar 1. Kesalahan siswa menyatakan sifat-sifat persegi dan persegi panjang

Dari jawaban siswa terlihat bahwa siswa tidak memahami konsep persegi panjang karena tidak bisa menyatakan ulang sifat-sifat persegi panjang dengan benar. Siswa juga tidak dapat menyatakan ulang sifat persegi dengan lengkap, serta siswa tidak dapat menggambarkan persegi serta persegi panjang. Pada soal nomor 2 juga banyak dijumpai kesalahan-kesalahan konsep:

Di antara beberapa benda dibawah ini, manakah yang merupakan bangun berbentuk limas Jelaskan alasanmu!

a.

b.
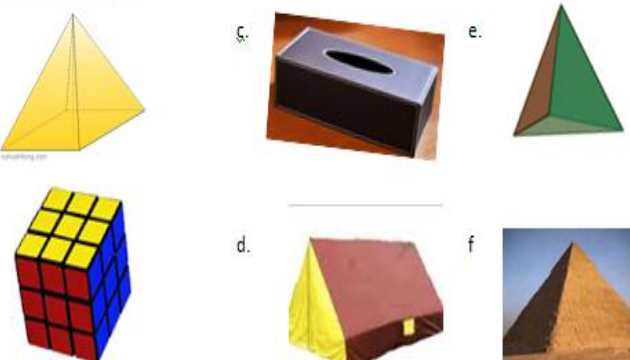

d.
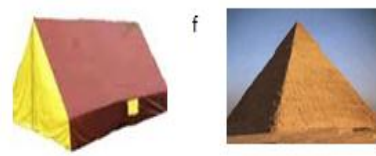

Gambar 2. Soal mengidentifikasi contoh dan non contoh dari bangun ruang limas

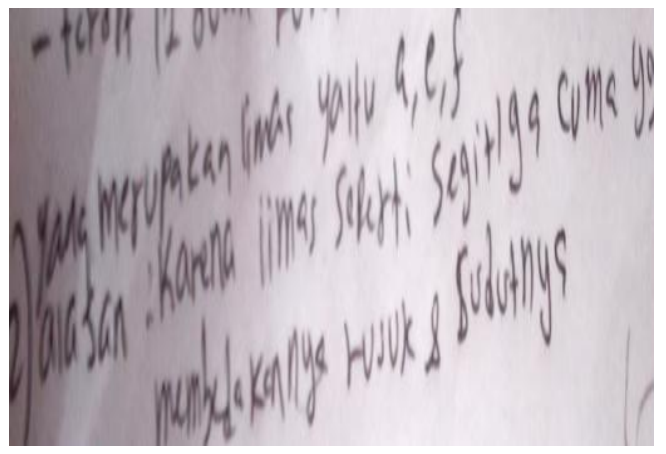

\section{Gambar 3. Kesalahan siswa menyatakan konsep limas}

Dari jawaban tersebut terlihat siswa sudah bisa mengidentifikasi contoh namun siswa belum mampu menjelaskan konsep limas. Hal tersebut menunjukkan bahwa siswa hanya menghapal gambar limas tanpa mengerti konsep dengan baik.

Pada soal selanjutnya juga terdapat banyak siswa yang salah menggunakan algoritma penyelesaian dalam pengerjaan soal. Soal selanjutnya adalah seperti berikut :

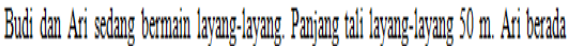

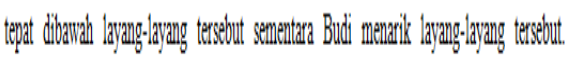

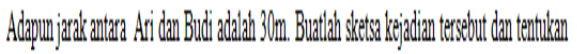

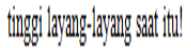

Gambar 4. Soal konsep phytagoras

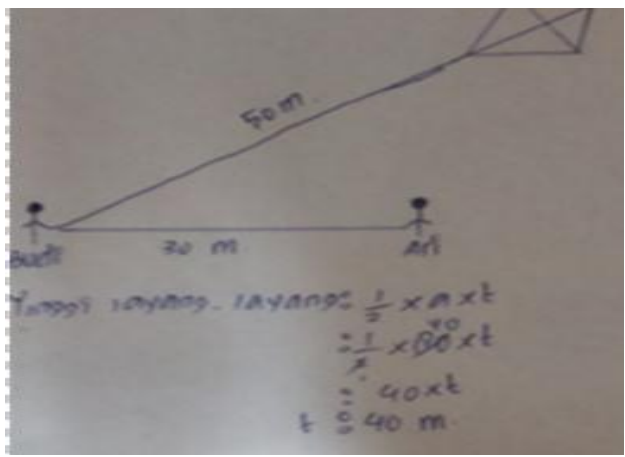

Gambar 5. Kesalahan siswa mengerjakan soal konsep phytagoras

Jawaban tersebut menunjukkan bahwa siswa tidak mampu memilih prosedur pemecahan masalah dengan tepat padahal siswa sudah dapat menggambarkan sketsanya. Siswa tidak memahami dengan benar konsep phytagoras yang sudah dipelajari sebelumnnya.

Untuk mengatasi permasalahanpermasalahan pembelajaran matematika yang terjadi saat ini maka perlu dilakukan perbaikan proses pembelajaran agar tercapai peningkatan kemampuan pemahaman konsep siswa. Diperlukan pembelajaran matematika

Mariani Manik, Mukhtar Penerapan Metode Penemuan Terbimbing dalam Upaya Meningkatkan Kemampuan Pemahaman Konsep Matematika di Kelas VIII SMP Negeri 1 Ajibata. Jurnal Inspiratif, Vol. 3, No. 2 Agustus 2017. 
yang bisa menghadirkan situasi belajar bermakna bagi siswa sehingga siswa tidak menghapal, namun juga memaknai pelajaran dengan baik.

Terdapat beberapa cara yang dapat dilakukan untuk mencapai pemahaman konsep matematika siswa yang baik. Salah satunya guru perlu merancang pembelajaran efektif, membuat siswa lebih aktif dalam proses pembelajaran sehingga dapat meningkatkan pemahaman konsep siswa terhadap suatu materi. Salah satu metode pengajaran yang diduga dapat digunakan untuk meningkatkan pemahaman konsep matematika adalah pembelajaran matematika melalui penerapan metode penemuan terbimbing (guided discovery).

Pembelajaran dengan metode penemuan terbimbing merupakan salah satu cara untuk menyampaikan ide/gagasan dengan proses menemukan, dalam proses ini siswa berusaha menemukan konsep dan rumus dan semacamnya dengan difasilitasi oleh guru. Dengan proses menemukan dan menyelidiki, maka hasil yang diperoleh akan setia dan tahan lama dalam ingatan, tidak akan mudah dilupakan siswa, pengertian yang ditemukan sendiri merupakan pengertian yang betul-betul dikuasai dan mudah digunakan atau ditransfer dalam situasi lain. Sesuai dengan pernyataan Bruner (dalam Dahar 2006:79) bahwa "belajar penemuan sesuai dengan pencarian pengetahuan secara aktif oleh manusia dengan sendirinya memberikan hasil yang paling baik. Berusaha sendiri untuk mencapai pemecahan masalah serta pengetahuan yang menyertainya, menghasilkan pengetahuan yang benarbenar bermakna". Dalam metode penemuan terbimbing ini guru memancing cara berpikir siswa yaitu dengan pertanyaan-pertanyaan terfokus sehingga dapat memungkinkan siswa untuk memahami dan mengkontruksikan konsep-konsep tertentu, membangun aturan-aturan dan belajar menemukan sesuatu untuk memecahkan masalah.

\section{Metode Penelitian}

Jenis penelitian yang digunakan adalah Penelitian Tindakan Kelas (classroom Action Research) yang dilakukan secara kolaboratif dengan guru kelas. Penelitian tindakan kelas ditandai dengan adanya tahap-tahap penelitian berupa siklus yang dilakukan dengan tujuan untuk meningkatkan kemampuan pemahaman konsep matematika siswa melalui penerapan metode penemuan terbimbing

Subjek dalam penelitian ini adalah siswa kelas VIII-A SMP Negeri 1 Ajibata sebanyak 30 siswa. Pengambilan kelas VIII-A sebagai subjek dilakukan berdasarkan dari hasil tes diagnostik yang menunjukkan bahwa kemampuan pemahaman konsep siswa masih rendah. Dari 30 siswa yang dites hanya 2 siswa $(6,66 \%)$ yang kemampuan pemahaman konsepnya tuntas mencapai nilai 75 (nilai KKM) sedangkan 28 siswa $(93,33 \%)$ tidak tuntas.

\section{Hasil Penelitian dan Pembahasan}

Berdasarkan hasil penelitian dapat disimpulkan bahwa pemahaman konsep matematika siswa pada materi Prisma dan limas melalui penerapan metode penemuan terbimbing telah mencapai target keberhasilan. Sebelum diberikan tindakan, peneliti terlebih dahulu memberikan tes diagnostik kepada siswa yang bertujuan untuk mengetahui kemampuan awal siswa dan kesulitan apa yang dihadapi siswa. Dari hasil tes diagnostik di kelas VIII-A diperoleh nilai rata-rata kelas adalah 58,83 dengan kategori rendah serta siswa yang tuntas secara klasikal hanya 2 siswa $(6,67 \%)$ dari 30 siswa. Setelah diberi tindakan pada siklus I melalui penerapan metode penemuan terbimbing rata-rata nilai kelas untuk tes pemahaman konsep I naik menjadi $70,91 \%$ dengan kategori

Mariani Manik, Mukhtar Penerapan Metode Penemuan Terbimbing dalam Upaya Meningkatkan Kemampuan Pemahaman Konsep Matematika di Kelas VIII SMP Negeri 1 Ajibata. Jurnal Inspiratif, Vol. 3, No. 2 Agustus 2017. 
sedang, serta siswa yang tuntas secara klasikal ada 14 siswa $(46,67 \%)$ dari 30 siswa. Walaupun ada peningkatan namun kriteria keberhasilannya belum tercapai yaitu minimal $80 \%$ siswa mencapai nilai $\geq 75$ sehingga pembelajaran dilanjutkan pda siklus II.

Pada siklus II yang merupakan perbaikan pembelajaran siklus I, dari hasil tes pemahaman konsep II rata-rata nilai kelas 81,91 dengan kategori Tinggi serta yang tuntas secara klasikal sebanyak 26 siswa $(86,67 \%)$ dari 30 siswa. Tidak ada lagi siswa dengan kemampuan pemahaman konsep rendah. Setelah melihat hasil penelitian ini, dapat dikatakan bahwa penerapan metode penemuan terbimbing merupakan salah satu upaya yang dapat meningkatkan kemampuan pemahaman konsep siswa. Pembelajaran dengan metode penemuan terbimbing merupakan salah satu cara untuk menyampaikan ide/gagasan dengan proses menemukan, dalam proses ini siswa berusaha menemukan konsep dan rumus dan semacamnya dengan difasilitasi oleh guru. Dengan proses menemukan dan menyelidiki, maka hasil yang diperoleh akan setia dan tahan lama dalam ingatan, tidak akan mudah dilupakan siswa, pengertian yang ditemukan sendiri merupakan pengertian yang betul-betul dikuasai dan mudah digunakan atau ditransfer dalam situasi lain. Sesuai dengan pernyataan Bruner bahwa "belajar penemuan sesuai dengan pencarian pengetahuan secara aktif oleh manusia dengan sendirinya memberikan hasil yang paling baik. Berusaha sendiri untuk mencapai pemecahan masalah serta pengetahuan yang menyertainya, menghasilkan pengetahuan yang benarbenar bermakna" (Dahar 2006:79). Bruner menyatakan bahwa dalam tahap awal pemahaman konsep diperlukan aktivitas-aktivitas konkret (nyata) yang mengantar siswa kepada pengertian konsep. Dalam menera PENGEMBANGAN PEMBELAJARAN BERBANTUAN
AUTOGRAPH UNTUK MENINGKATKAN PEMAHAMAN KONSEP MATEMATIK SISWA SMK MELALUI MODEL PENEMUAN TERBIMBING pkan pembelajaran Penemuan Terbimbing ini kepada siswa, peneliti juga menggunakan LAS yang berkaitan dengan kehidupan sehari-sehari, ini sesuai juga dengan pendapat Bruner pada tahap enaktif yaitu dalam memahami konsep siswa harus aktif belajar dan terlibat langsung dalam menemukan konsep.

Dengan Penerapan Metode Penemuan Terbimbing siswa lebih tertarik dan termotivasi pada materi yang diajarkan, mampu membangkitkan pengalaman siswa sebab siswa diajak terlibat langsung, membuat siswa aktif belajar dan lebih bersemangat, memperkuat ingatan siswa tentang materi yang diajarkan. Selain itu juga dapat meningkatkan kemampuan siswa dalam berpikir dan juga meningkatkan rasa ingin tahu siswa serta kreatifitas siswa dalam menemukan konsep sehingga pelajaran menjadi lebih bermakna. Hal tersebut sejalan dengan penelitian oleh Yang, dkk (2010) menyatakan bahwa "siswa mempelajari konsep lebih baik jika terlibat dalam proses menemukan. Termasuk mengamati beberapa contoh konsep , mencari dan menguji pola balik contohcontoh, dan generalisasi temuan mereka dengan kata-kata tertulis yang tepat". Selain Yang, peneliti lain yaitu Matthew di Taraba State, Nigeria (2013) juga melakukan penelitian untuk mengetahui kemampuan pemahaman konsep siswa dengan menerapkan metode penemuan terbimbing. Mattew meengungkapkan bahwa "siswa yang diajarkan menggunakan metode pengajaran penemuan terbimbing memiliki nilai prestasi lebih baik daripada siswa yang diajarkan dengan menggunakan metode pembelajaran konvensional" begitu juga hasil penelitian Wasriona, Surya dan Syahputra, (2015).

Mariani Manik, Mukhtar Penerapan Metode Penemuan Terbimbing dalam Upaya Meningkatkan Kemampuan Pemahaman Konsep Matematika di Kelas VIII SMP Negeri 1 Ajibata. Jurnal Inspiratif, Vol. 3, No. 2 Agustus 2017. 


\begin{abstract}
Adapun kelemahan peneliti selama pembelajaran berlangsung diantaranya tidak semua siswa bisa memahami materi relevan apa yang diperlukan untuk menemukan konsep karena sudah terbiasa dengan pembelajaran sebelumnya dimana siswa langsung diberikan konsep secara utuh. Selain itu siswa juga takut salah dan kurang percaya diri dengan jawabannya sehingga siswa bertanya-tanya pada temannya membuat suasana menjadi tidak kondusif. Karena sudah terbiasa diberitahu langsung oleh guru membuat tingkat kepercayaan dirinya atas kemampuannya pun menjadi berkurang. Siswa berpatokan bahwa jawaban yang benar hanyalah jawaban guru. Hal tersebut membuat kemampuan siswa menjadi terbatas. Saat pembelajaran, karena terbatasnya persediaan bendabenda di sekitar lingkungan sekolah yang merupakan contoh Prisma dan limas sangatlah sedikit sehingga tidak semua kelompok mendapatkannya. Dengan demikian berbagai kelemahan dalam penelitian ini masih perlu dikembangkan untuk mendapatkan hasil yang baik.
\end{abstract}

\section{Kesimpulan}

Dari hasil penelitian yang dilakukan dan pembahasan yang telah diuraikan maka diperoleh kesimpulan bahwa :

1. Pemahaman konsep matematika siswa kelas VIII-A di SMP Negeri 1 Ajibata mengalami peningkatan dari tes diagnotik ke tes pemahaman konsep I setelah diterapkannya metode penemuan terbimbing. Namun pada siklus I peningkatan yang diperoleh belum mencapai kriteria keberhasilan sehingga perlu dilanjutkan ke siklus II. Pada siklus II dilakukan beberapa perbaikan yaitu perbaikan rancangan pembelajaran dan pergantian kelompok heterogen. Dengan menerapkan metode penemuan terbimbing dengan berbantukan lembar aktivitas siswa (LAS) yang berisi instruksi-instruksi yang mengarahkan siswa untuk menemukan konsep dengan mengkontruksi sendiri pengetahuannya dan dibantu oleh bimbingan guru, maka kemampuan siswa dalam memahami konsep semakin meningkat.

2. Aktifitas siswa setelah diterapkannya metode penemuan terbimbing juga mengalami peningkatan. Hal ini dikarenakan langkah-langkah dalam metode penemuan terbimbing mendukung siswa untuk terlibat aktif dan menjadikan siswa sebagai pusat pembelajaran. Selain itu, adanya diskusi kelompok dan presentasi siswa juga melatih keaktifan siswa dalam proses pembelajaran.

\section{Saran}

Adapun saran yang diajukan berdasarkan hasil penelitian ini, yaitu : 1.Kepada guru, khususnya guru matematika disarankan untuk menerapkan metode Penemuan Terbimbing pada materi lainnya dan juga menggunakan LAS. Agar hasil pembelajaran dengan metode Penemuan Terbimbing ini maksimal, guru sebaiknya memberikan motivasi terlebih dahulu dan memberikan insturksi serta bimbingan yang tepat yang dapat menuntun siswa agar tidak kesulitan saat terlibat dalam proses penemuan.

2.Kepada siswa SMP Negeri 1 Ajibata disarankan lebih berani dan aktif saat berlangsung proses pembelajaran, aktif dalam menemukan solusi-solusi permasalahan, aktif dalam kerja kelompok, berani untuk mengungkapkan ide-ide secara terbuka, serta percaya diri dengan kemampuan sendiri.

3.Kepada peneliti lain disarankan agar hasil penelitian ini dijadikan sebagai pertimbangan untuk menerapkan metode penemuan terbimbing pada materi lain untuk penelitian selanjutnya dan memperhatikan kelemahan-kelemahan

Mariani Manik, Mukhtar Penerapan Metode Penemuan Terbimbing dalam Upaya Meningkatkan Kemampuan Pemahaman Konsep Matematika di Kelas VIII SMP Negeri 1 Ajibata. Jurnal Inspiratif, Vol. 3, No. 2 Agustus 2017. 
yang ada peneliti, sehinggga penelitian yang dilakukan semakin baik. sendirinya memahami dan mempelajari materi yang diajarkan.

Bagi guru-guru atau calon guru yang akan menerapkan model pembelajaran kooperatif agar memperhatikan dan mengatur alokasi waktu yang ada secara cermat agar langkah-langkah pembelajaran dapat dilaksanakan secara optimal.

\section{DAFTAR PUSTAKA}

Abdurrahman, Mulyono. 2012. Pendidikan Bagi Anak Berkesulitan Belajar. Jakarta: PT. Rineka Cipta.

Asmani, Jamal Ma'mur. 2011. Tips Pintar PTK: Penelitian Tindakan Kelas. Yogyakarta: Laksana.

Dahar, Ratna Wilis. 2006. Teori-teori Belajar Dan Pembelajaran. Bandung: Erlangga.

Depdiknas. 2006. Peraturan Menteri Pendidikan Nasional Republik Indonesia No 22 Tahun 2006 tentang Standar Isi Untuk Satuan Pendidikan Dasar Dan Menengah. Permendiknas-no-22tahun-2006-standar-isi.Pdf

FMIPA Unimed. 2010. Pedoman Penulisan Proposal dan Skripsi Mahasiswa Program Studi Pendidikan FMIPA Medan. Medan: Unimed.

Hakiim, Lukmanul. 2009. Perencanaan Pembelajaran. Bandung: CV Wacana Prima.

Hariyati, Indaryanti, dan Zulkardi. 2008. Pengembangan Materi Luas Permukaan Dan Volum Limas Yang Sesuai Dengan Karakteristik PMRI Di Kelas VIII
SMP Negeri 4 Palembang. Jurnal Pendidikan Matematika. Volume 2. No.1. http://eprints.unsri.ac.id./799/1/U RUT 5 GANJIL.Pdf

Harja. 2012. Pemahaman Konsep Matematis, mediaharja.blogspot.com/2012/05 pemahaman-konsepmatematis.html?m=.

Hudojo, H. 2001. Pengembangan Kurikulum dan Pembelajaran Matematika. Malang: Universitas Negeri Malang.

Karim, Asrul. 2011. Penerapan Metode Penemuan Terbimbing Dalam Pembelajaran Matematika Untuk Meningkatkan Pemahaman Konsep Dan Kemampuan Berpikir Kritis Siswa Sekolah Dasar. Jurnal Pendidikan. Edisi Khusus No.1. http://jurnal. upi.edu/file/3-Asrul_Karim.pdf.

Markaban. 2006. Model Pembelajaran Matematika dengan Pendekatan Penemuan Terbimbing. Departemen Pendidikan Nasional Pusat Pengembangan Dan Penataran Guru Matematika. Yogyakarta: PPPPTK Matematika.http://p4tk.matematik a.org/downloads/ppp/PPP_Penem uan terbimbing.pdf.

Matthew, B \& Igharo O Kenneth. 2013. A Study On The Effects Of Guided Inquiry Teaching Method On Students Achievement In Logic. International Researcer 2(1): 134140.

Napitupulu, Ester L. 2012. Prestasi Sains dan Matematika Indonesia Menurun. Harian Kompas. 14 Desember 2012. (Online). http://edukasi.kompas.com.

Mariani Manik, Mukhtar Penerapan Metode Penemuan Terbimbing dalam Upaya Meningkatkan Kemampuan Pemahaman Konsep Matematika di Kelas VIII SMP Negeri 1 Ajibata. Jurnal Inspiratif, Vol. 3, No. 2 Agustus 2017. 
Nuharini, Dewi dan Tri Wahyuni. 2008. BSE Matematika dan Aplikasinya 2 Kelas VIII Untuk SMP/MTs. Jakarta: Depdiknas.

Pasaribu, Endi Zunaedy 2015. Peningkatan Kemampuan Pemahaman Dan Disposisi Matematis Siswa Melalui Model Pembelajaran

Penemuan Terbimbing Di Mtsn 1 Padangsidempuan. Tesis. Tidak diterbitkan. Medan: Unimed.

Rahmadani, Elfira.

2015. Pengembangan Perangkat Pembelajaran Berbasis Model Discovery Learning Untuk Meningkatkan Kemampuan Pemahaman Konsep Dan Disposisi Matematis Siswa Berbantukan Geoboard. Tesis. Tidak diterbitkan. Medan: Unimed.

Shoimin, Aris. 2014. 68 Model Pembelajaran Inovatif dalam Kurikulum 2013. Jakarta: Ar:Ruzz Media.

Sani, Ridwan Abdullah. 2014. Inovasi Pembelajaran. Jakarta: Bumi Aksara.

Sudjana, N. 2009. Penilaian Hasil Belajar Mengajar. Bandung : PT. Remaja Rosdakarya.

Surya, E. and Syahputra, E. 2017. Improving High-Level Thinking Skills by Development of Learning PBL Approach on The Learning Mathematics for Senior High School Students. International Education Studies Journal, 10(8), 12-20.

Suryosubroto, B. 2009. Proses Belajar Mengajar di Sekolah. Jakarta: Rineka Cipta.
Tim PPPG Matematika. 2004. Modelmodel Pembelajaran Matematika SMP. Yogyakarta: PPPG Matematika.

Trianto. 2011. Mendesain Model Pembelajaran Inovatif-progresif. Jakarta: Kencana Prenada Media Grup.

Wardhani, S. 2008. Analisis SI dan SKL Mata Pelajaran Matematika SMP/MTs untuk Optimalisasi Pencapaian Tujuan. Yogyakarta: Pusat Pengembangan dan Pemberdayaan Pendidik dan Tenaga Kependidikan Matematika (PPPPTK).

Wasriono. Surya, E., Syahputra, E. 2015. Pengembangan Perangkat Pembelajaran Berbantuan Autograph untuk Meningkatkan Pemahaman Konsep Matematik Siswa SMK Melalui Model Penemuan Terbimbing. Paradikma Jurnal Pendidikan Matematika, 8(3), 52-61.

Yamin, Martinis. 2013. Strategi dan Metode dalam Model Pembelajaran. Jakarta: Gaung Persada Press Group.

Yang, Eufhony F.Y, DKK. 2010. The Effectiveness of Inductive Discovery Learning in 1:1 Mathematics Classroom. http://www.icce2010.upm. edu.my/papers/c6/short\%20paper/ C6SP200.pdf.

Ziswan, Delnedi. 2014. Upaya Meningkatkan Kemampuan Guru dalam Menyusun Rencana Pelaksanaan pembelajaran Kurikulum $2013 \quad$ Melalui Workshop Pada SMKN 4 Kota Jambi. Tesis. Medan: Unimed.

Mariani Manik, Mukhtar Penerapan Metode Penemuan Terbimbing dalam Upaya Meningkatkan Kemampuan Pemahaman Konsep Matematika di Kelas VIII SMP Negeri 1 Ajibata. Jurnal Inspiratif, Vol. 3, No. 2 Agustus 2017. 